\title{
Cytotoxic and apoptotic activities of black widow spiderling extract against HeLa cells
}

\author{
XIAOZHEN PENG ${ }^{1}$, ZHIPAN DAI $^{1}$, QIAN LEI $^{1}$, LONG LIANG $^{2}$, SHUAI YAN $^{1}$ and XIANCHUN WANG ${ }^{1}$ \\ ${ }^{1}$ Key Laboratory of Protein Chemistry and Developmental Biology of the Ministry of Education, \\ College of Life Sciences, Hunan Normal University, Changsha, Hunan 410081; ${ }^{2}$ Department of Cell Biology, \\ School of Life Sciences, Central South University, Changsha, Hunan 410013, P.R. China
}

Received September 22, 2015; Accepted January 26, 2017

DOI: $10.3892 / \mathrm{etm} .2017 .4391$

\begin{abstract}
Black widow spiders contain toxic components not only in the venom glands but also in other parts of the spider body, including the legs and abdomen. Additionally, both the eggs and newborn spiderlings of the black widow spider contain venom. It is important to investigate their potential effects on cancer cells. In the present study, the effects of newborn black widow spiderling extract on human HeLa cells were evaluated in vitro. When applied at different concentrations, the total extract decreased HeLa cell viability in a dose-dependent manner, with an $\mathrm{IC}_{50}$ value of $158 \mu \mathrm{g} / \mathrm{ml}$. Flow cytometry indicated that treatment of HeLa cells with the total extract of the spiderlings induced apoptosis in HeLa cells in a dose-dependent manner and led to cell cycle arrest in the S-phase. Additionally, application of the total extract at different concentrations increased apoptosis-related caspase 3 activity in a dose-dependent manner. HeLa cells treated with the total extract appeared to be morphologically changed, exhibiting membrane blebbing, nuclear fragmentation and condensation of chromatin. Further separation and activity screening demonstrated that the cytotoxic and apoptotic activities of the total extract were attributable mainly to its high molecular mass proteins, one of which was purified and characterized to determine its anti-tumor activities on HeLa cells. The results of the present study therefore have expanded understanding regarding the effect of spider toxins on cancer cells and suggested that components of black widow spiderlings may be developed as a promising novel agent to treat cancer.
\end{abstract}

Correspondence to: Professor Xianchun Wang, Key Laboratory of Protein Chemistry and Developmental Biology of the Ministry of Education, College of Life Sciences, Hunan Normal University, 36 Lushan South Road, Changsha, Hunan 410081, P.R. China

E-mail: wang_xianchun@263.net

Key words: black widow spider, spiderling, extract, HeLa cell, cell viability, apoptosis

\section{Introduction}

Cancer is a leading cause of mortality worldwide (1,2). Globally, it is estimated that there are currently $>10$ million cases of cancer diagnosed per year and that there will be $\sim 13.1$ million cases of cancer-associated mortality per year by 2030 (3). Cancer cells are considered to have lost their apoptotic ability and undergo accelerated and uncontrolled proliferation. Over the past few decades, many studies have been conducted to identify the factors that promote uncontrolled proliferation of cancer cells and determine how cancer genes affect the physiological and biochemical processes $(4,5)$. A number of studies have examined the anti-tumor substances found in the venoms of various animals including snakes (6), scorpions (7), toads (8), bees (9) and spiders (10).

In developing countries, cervical cancer is the most commonly diagnosed gynecological tumor $(11,12)$. Globally, by 2030 it is estimated that $\sim 500,000$ women a year will suffer from cervical cancer and the overall number of cervical cancer cases will increase by $>11$ million $(13,14)$. Although a considerable effort has been made, current primary treatments such as surgery, chemotherapy and radiotherapy have not achieved satisfactory effects $(13,15)$. This is primarily because these treatments often destroy the healthy tissues surrounding the tumors or cause undesirable side effects (16). In addition, tumor cells are able to develop resistance to certain therapies and thus weaken the treatment effects (17). It is therefore important to develop more efficient drugs that produce fewer side effects to treat this disease. Using the cytotoxic and anti-tumor components found in animal venom to develop novel pharmaceutical compounds may be a potential therapeutic strategy.

The black widow spider is one of the most poisonous spiders in the world. It differs from other venomous animals in that it not only harbors toxic components in the venom glands, but also in other parts of the adult spider body, including the legs and abdomen. Furthermore, both the eggs and newborn spiderlings of the black widow spider contain venom (18-20). Previously, the venom of the spider has been extensively investigated (21-24). At least seven different latrotoxins have been purified and characterized from the venom of the spider. The majority of which are targeted against insects and are called latroinsectotoxins (LITs; $\alpha, \beta, \gamma, \delta, \varepsilon$-LIT) (24). Comparatively, there are fewer reports on the toxicity of the components 
outside the venomous glands of black widow spider. In fact, a number of studies have demonstrated that the toxins found in the eggs and spiderlings of the black widow spider differ from those identified in the venom of the adult spider $(19,25)$. For example, Kobert (26) conducted a number of experiments and concluded that the poison from newborn black widow spiderlings produced hemolysis and defects in coagulation. Furthermore, it was demonstrated that intradermic injection of the spiderling extract into rabbits produced localized hemorrhages (19). A previous study by the current authors demonstrated that abdominal injection of newborn black widow spiderling total extract into mice and cockroaches caused marked symptoms of poisoning, as well as mortality. The extract was able to block neuromuscular transmission in isolated mouse nerve-hemidiaphragm preparations and inhibit voltage-activated $\mathrm{Na}^{+}, \mathrm{K}^{+}$and $\mathrm{Ca}^{2+}$ channel currents in rat dorsal root ganglion neurons (27). These results demonstrate that black widow spiderlings are rich in cytotoxic and neurotoxic components as well as other bioactive components. Thus the spiderling extract may have beneficial effects on killing cancer cells $(15,16)$. Obviously, investigation on the effects of spiderling extract on cancer cells has important theoretical and practical significance. In the present study, the components toxic to HeLa cells from the newborn black widow spiderling extract were screened and evaluated in vitro. It was determined that the extract, particularly its high molecular mass protein components, was able to effectively decrease the viability of HeLa cells and induce their apoptosis.

\section{Materials and methods}

Materials. Fetal bovine serum (FBS; Gibco, Thermo Fisher Scientific, Inc., Waltham, MA, USA), cell counting kit-8 (CCK-8; Dojindo Molecular Technologies, Inc., Kumamoto, Japan), Hoechst 33342 (Beijing Solarbio Science \& Technology Co., Ltd., Beijing, China), dimethyl sulfoxide (Sigma-Aldrich; Merck KGaA, Darmstadt, Germany), dithiothreitol (Sigma-Aldrich, Merck KGaA), N, N, N', N'-tetramethylethylenediamine (GE Healthcare Life Sciences, Uppsala, Sweden), trihydroxymethy aminomethane (Tris; Bio-Rad, Hercules, CA, USA) were used in the present study. The caspase 3 activity assay kit (Beyotime Institute of Biotechnology, Shanghai, China) and the Bradford protein assay kit (P006, Beyotime Institute of Biotechnology) were also used. The HeLa cell line was obtained from the Cell Bank of the Chinese Academy of Sciences (Wuhan, China; cat. no. TCHu 187).

Spiderling total extract preparation and fractionation. Aqueous extract was prepared from $\sim 5 \mathrm{~g}$ of newly hatched spiderlings collected from black widow spider egg sacs gathered from the Xinjiang Uighur Autonomous Region of China. After the spiderlings were homogenized with a pestle in a mortar in deionized water on ice, the homogenate was centrifuged at $10,000 \mathrm{xg}$ for $10 \mathrm{~min}$ at $4^{\circ} \mathrm{C}$. The supernatant was then collected and the pellet was repeatedly homogenized in the mortar and centrifuged under the same conditions twice. Supernatants were combined and lyophilized or appropriately concentrated to increase the protein concentration to $15-20 \mathrm{mg} / \mathrm{ml}$ so it was suitable for subsequent analysis.
To obtain more detailed information regarding the active components in newborn spiderlings, the total extract was fractionated and the effects of resulting fractions on HeLa cells were assessed, respectively. Briefly, the spiderling extract was first fractionated by ultrafiltration with a $10 \mathrm{kDa}$ ultrafilter (UFC901096, EMD Millipore, Billerica, MA, USA) into a high $(>10 \mathrm{kDa})$ and low $(<10 \mathrm{kDa})$ molecular mass fractions. For facilitating the fractionation, centrifugation at 5,000 $\mathrm{x} g$ for 10 min at $4^{\circ} \mathrm{C}$ was used. Subsequently, the high molecular mass fraction was further fractionated into several subfractions with HPLC using a gel filtration chromatographic column $(2.6 \mathrm{~cm}$ inside diameter x60 cm long; GE Healthcare Bio-Sciences, Pittsburgh, PA, USA) packed with Sephacryl S-100 High Resolution (GE Healthcare Bio-Sciences, Pittsburgh, PA, USA). The desired subfraction from the gel filtration chromatography was selected for further purification by an $\mathrm{XBridge}^{\mathrm{TM}}$ BEH300 C4 reversed-phase column $(4.6 \times 150 \mathrm{~mm}$, Waters Corporation, Milford, MA, USA) on a Waters High Performance Liquid Chromatography with a 996-photodiode array detector (HPLC system; Waters Corporation). For the chromatographic separation, $50 \mu 1$ sample ( 1 mg protein) was loaded each run. Solvent A (0.05\% trifluoroacetic acid) and solvent B (acetonitrile containing $0.05 \%$ trifluoroacetic acid) were used as eluting buffers. Flow rate was set at $1.0 \mathrm{ml} / \mathrm{min}$. The main eluted peak was collected and lyophilized. The molecular mass distribution of the proteins in the subfractions and the purity of the purified protein sample were detected by SDS-PAGE (11.5\% gel) under denaturation conditions according to the method of Laemmli (28).

Cell culture. HeLa cells from the Cell Bank of the Chinese Academy of Sciences (Wuhan, China) were cultured in Dulbecco's modified Eagle's medium (DMEM; Thermo Fisher Scientific, Inc.) containing 10\% FBS, $100 \mu \mathrm{g} / \mathrm{ml}$ streptomycin (Sangon Biotech Co., Ltd., Shanghai, China) and $100 \mathrm{U} / \mathrm{ml}$ penicillin (Sangon Biotech Co., Ltd.) in an incubator at $37^{\circ} \mathrm{C}$, with $5 \% \mathrm{CO}_{2}$ and saturated humidity. The cells were studied at logarithmic growth phase. All procedures were performed on a super-clean bench and sterile conditions were maintained.

Effect of spiderling extract on HeLa cell viability. The effects of the extract on cell viability were assessed using a CCK-8 assay. Cells $\left(2 \times 10^{4} /\right.$ well $)$ were seeded in a 96-well microplate in a final volume of $100 \mu \mathrm{l}$. Following attachment for $48 \mathrm{~h}$, the cells in each well were separately treated with the extract at different final concentrations [0 (control), 1, 10, 100, 300, 600, $900 \mu \mathrm{g} / \mathrm{ml}]$. Then, $10 \mu \mathrm{l} \mathrm{CCK-8} \mathrm{solution} \mathrm{was} \mathrm{added} \mathrm{to} \mathrm{each}$ well and incubation proceeded at $37^{\circ} \mathrm{C}$ for $2 \mathrm{~h}$. Absorbance at $450 \mathrm{~nm}$ was detected using a Multimode Plate Reader (ELx800; BioTek Instruments, Inc., Winooski, VT, USA).

Effects of spiderling extract on cell cycle and apoptosis in HeLa cells. The effects of the spiderling extract on the cell cycle and apoptosis in HeLa cells were assessed using flow cytometry according to the methods previously described $(8,29)$. After the HeLa cells were cultured in DMEM medium containing $10 \%$ FBS in 6-well plates $\left(1 \times 10^{6} /\right.$ well $)$ at $37^{\circ} \mathrm{C}$ for $24 \mathrm{~h}$, cells were incubated for $24 \mathrm{~h}$ with different concentrations of the extract [0 (control), 1, 10, 40, 60, 80, $100 \mu \mathrm{g} / \mathrm{ml}]$. Treated cells were harvested by centrifugation at $1,000 \times g$ for $3 \mathrm{~min}$ at $4^{\circ} \mathrm{C}$, 
followed by washing twice in PBS at room temperature and fixing with $70 \%$ ethanol overnight at $4^{\circ} \mathrm{C}$. The ethanol was removed by centrifugation at $1,000 \times \mathrm{g}$ for $3 \mathrm{~min}$ at room temperature. Following washing with PBS twice, the cells were resuspended in $1 \mathrm{X}$ fluorescence-activated cell sorting (FACS) buffer containing 0.2\% Triton X-100, $200 \mu \mathrm{l}$ annexin V-FITC (ab14085, Abcam, Cambridge, UK), $50 \mu \mathrm{g} / \mathrm{ml}$ propidium iodide (ab14083, Abcam, Cambridge, UK), $100 \mu \mathrm{g} / \mathrm{ml}$ RNase $\mathrm{A}$ in PBS, incubated at $4^{\circ} \mathrm{C}$ for $30 \mathrm{~min}$ in the dark, and analyzed using a BD FACSCalibur ${ }^{\mathrm{TM}}$ flow cytometer with BD FACStation $^{\mathrm{TM}}$ software, version 6.1 (BD Biosciences, Franklin Lakes, NJ, USA).

Detection of apoptotic morphological changes of HeLa cells caused by spiderling extract. HeLa cells were seeded into 96 -well plates $\left(1 \times 10^{6} /\right.$ well $)$ and incubated with the extract [0 (control), 1 and $100 \mu \mathrm{g} / \mathrm{ml}$ ] for $24 \mathrm{~h}$. Following removal of the culture medium, the morphology of the cells was observed. For nucleus staining with Hoechst 33342, the cells were washed twice with PBS and then fixed in $4 \%$ paraformaldehyde for $20 \mathrm{~min}$ at room temperature, followed by treatment with $10 \mu \mathrm{g} / \mathrm{ml}$ Hoechst 33342 solution for $30 \mathrm{~min}$. Following three washes with PBS, images were captured by fluorescent microscopy (TE2000; Nikon Corporation, Tokyo, Japan).

Effects of spiderling extract on caspase 3 activity in HeLa cells. Caspase 3 activity in HeLa cells was measured using a commercially available caspase 3 assay kit according to the protocol supplied by the manufacturer. Briefly, HeLa cells were cultured at $1 \times 10^{6}$ cells/well in 6-well plates and incubated with different concentrations of extract [0 (control), 10, 50, $100,150,200 \mu \mathrm{g} / \mathrm{ml}]$ for $24 \mathrm{~h}$. At the end of the treatment, cells were collected and lysed by the addition of lysis buffer from the caspase 3 assay kit. Aliquots of the cell lysate were added to a 96-well plate and incubated with caspase 3 substrate at $37^{\circ} \mathrm{C}$ for $2 \mathrm{~h}$. Absorbance in the wells was measured at $405 \mathrm{~nm}$. The protein in the lysate was quantitatively measured using the Bradford protein assay kit (Beyotime Institute of Biotechnology, Shanghai, China) following the manufacturer's protocol. The relative activity of the caspase 3 to convert its substrate (Ac-DEVD-pNA) was expressed as the enzyme unit per $\mu \mathrm{g}$ protein, where one enzyme unit is defined as the amount of enzyme that will cleave $1.0 \mathrm{nmol}$ of the colorimetric substrate Ac-DEVD-pNA per hour at $37^{\circ} \mathrm{C}$ and under saturated substrate concentrations.

Statistical analysis. All experiments were performed in triplicate. One-way analysis of variance was used for statistical analysis. Results were expressed as the mean \pm standard deviation. Difference was considered statistically significant at a confidence interval of $95 \%(\mathrm{P}<0.05)$ or extremely significant at a confidence interval of $99 \%(\mathrm{P}<0.01)$.

\section{Results}

Cytotoxic and apoptotic activities of the total extract. Evidence from previous studies has demonstrated that newborn black widow spiderlings harbor biologically active components $(19,20,27)$. As the first step of a systematic screening of the cytotoxic and apoptotic activities against HeLa cells, the effects of spiderling total extract on the cell viability, cell cycle, apoptosis induction, cell morphology and caspase 3 activity in HeLa cells were investigated.

Inhibition of HeLa cell viability by the total extract. The effect of the spiderling total extract on HeLa cell viability was investigated. Following treatment of the cells were treated with different concentrations $(0,1,10,100,300,600$ and $900 \mu \mathrm{g} / \mathrm{ml})$ of the spiderling total extract for $48 \mathrm{~h}$, a CCK- 8 assay was used to assess cell viability. The total extract was found to decrease cell viability in a dose-dependent manner (Fig. 1). When the total extract was applied at the aforementioned concentrations, compared with the control (100\%), the respective cell viabilities of HeLa cells were 90.61 $\pm 4.50(\mathrm{P}<0.05), 87.66 \pm 2.04$, $71.17 \pm 1.43,26.92 \pm 2.193,16.08 \pm 1.503$ and $1.52 \pm 0.323 \%$ (all $\mathrm{P}<0.01)$. The half maximal inhibitory concentration $\left(\mathrm{IC}_{50}\right)$ was calculated to be $158 \mu \mathrm{g} / \mathrm{ml}$.

Effects of the total extract on apoptosis and the cell cycle in HeLa cells. Following incubation of HeLa cells with the spiderling total extract at concentrations of $0,1,10,40,60$, 80 and $100 \mu \mathrm{g} / \mathrm{ml}$ for $24 \mathrm{~h}$, the effects of the extract on the apoptosis induction and cell cycle in HeLa cells were assessed using flow cytometry. Fig. 2A presents the dose-response effects of the total extract on the apoptotic rate of HeLa cells. It was observed that when the concentration of the extract was $1 \mu \mathrm{g} / \mathrm{ml}$, the apoptotic rate $(0.79 \pm 0.19 \%)$ of the HeLa cells did not differ significantly from the control. However, at concentrations of $\geq 10 \mu \mathrm{g} / \mathrm{ml}$ greater, apoptotic rates increased in a dose-dependent manner, to 2.18 $\pm 0.51,14.33 \pm 0.97(\mathrm{P}<0.05)$, $16.70 \pm 1.09,18.68 \pm 0.07$ and $30.60 \pm 2.35 \%(\mathrm{P}<0.01)$. These data indicate that the total extract of the black widow spiderling contains bioactive components that can induce apoptosis in HeLa cells.

The present study analyzed the cell cycle profiles of HeLa cells incubated with $0,1,10$ and $100 \mu \mathrm{g} / \mathrm{ml}$ total extract (Fig. 2B). In the control group, the percentages of the cells in the $\mathrm{G} 0 / \mathrm{G} 1, \mathrm{~S}$ and $\mathrm{G} 2 / \mathrm{M}$ phase were $60.74 \pm 0.08,20.60 \pm 4.23$ and $18.66 \pm 4.31 \%$, respectively. Following treatment of the cells for $24 \mathrm{~h}$ with the extract at lower concentrations ( 1 and $10 \mu \mathrm{g} / \mathrm{ml}$ ), the percentage of the HeLa cells in the G0/G1 phase decreased to $57.10 \pm 1.23$ and $52.25 \pm 1.42 \%$, respectively and the proportion of the cells in the S-phase increased to $24.01 \pm 2.23$ and $30.08 \pm 1.09 \%(\mathrm{P}<0.05)$, respectively, whereas the percentage of cells in the $\mathrm{G} 2 / \mathrm{M}$ phase was not evidently changed (18.89 \pm 4.0 and $17.67 \pm 1.95 \%)$. However, when the extract concentration was increased to $100 \mu \mathrm{g} / \mathrm{ml}$, the percentages of HeLa cells in the $\mathrm{G} 0 / \mathrm{G} 1, \mathrm{~S}$ and $\mathrm{G} 2 / \mathrm{M}$ phases were $57.67 \pm 6.35,17.10 \pm 11.62$ and $25.23 \pm 6.03 \%$, respectively, and were not significantly different from those of the control.

Observations of morphological changes and apoptosis in HeLa cells treated with the total extract. Effect of the spiderling total extract on HeLa cell morphology and apoptosis are shown in Fig. 3. In the control group, the morphology of cells was normal and uniform. Application of the extract induced clusters of HeLa cells and morphological changes in some cells. Treatment with $1 \mu \mathrm{g} / \mathrm{ml}$ extract caused a number of cells to cluster, however no obvious changes in cellular morphology was observed. Following treatment with $100 \mu \mathrm{g} / \mathrm{ml}$ extract for 


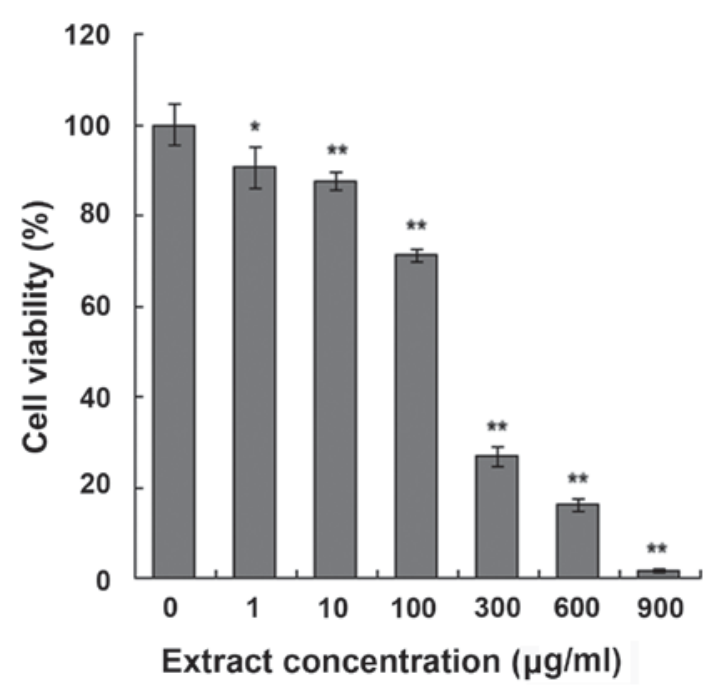

Figure 1. Effect of spiderling total extract on HeLa cell viability. Following incubation of HeLa cells with different concentrations of the extract $(0,1,10$, $100,300,600$ and $900 \mu \mathrm{g} / \mathrm{ml}$ ) for $48 \mathrm{~h}$, they were subjected to a cell counting kit- 8 assay. The percentage of cell viability was calculated for each group by normalization of the readings at $450 \mathrm{~nm}$ against the absorbance of untreated control HeLa cells, which was determined as $100 \%$ cell viability. Data were represented as the mean \pm standard deviation from three independent experiments. ${ }^{*} \mathrm{P}<0.05$ and ${ }^{* *} \mathrm{P}<0.01$ vs. control.

$24 \mathrm{~h}$, the bulk of the cells appeared to be undergo morphological changes, including membrane blebbing and apoptotic body formation (Fig. 3A). Nucleus staining of HeLa cells with Hoechst 33342 and fluorescence microscopy were used to further evaluate the effect of the extract on apoptosis (Fig. 3B). It was demonstrated that treatment with the extract led to an increase in the number of HeLa cells exhibiting a bright blue color, nuclear fragmentation and condensation of chromatin, all of which are typical characteristics of apoptotic cells. This demonstrates that the extract is able to induce apoptosis.

Stimulation of HeLa cell caspase 3 activity by the total extract. In order to determine the effect of the total extract on caspase 3 activity in HeLa cells, the cells were incubated with the total extract at different concentrations for $24 \mathrm{~h}$. HeLa cells were subsequently separated from the culture and lysed prior to the caspase 3 activity assay. Enzyme activity was expressed as enzyme unit (U) per $\mu \mathrm{g}$ protein. The results demonstrated that following incubation of the HeLa cells with $0,10,50,100,150$ or $200 \mu \mathrm{g} / \mathrm{ml}$ extract, the corresponding activities of the caspase 3 in HeLa cell lysate were $421.65 \pm 10.32,438.77 \pm 11.93,870.98 \pm 8.78$, $1,061.28 \pm 35.42,1,111.03 \pm 68.88$ and $1,226.68 \pm 76.28 \mathrm{U} / \mu \mathrm{g}$ protein, respectively. Compared with the control, concentrations of the extract $>10 \mu \mathrm{g} / \mathrm{ml}$ significantly increased the activity of caspase 3 in the HeLa cells $(\mathrm{P}<0.01$; Fig. 4).

Activity detection of low molecular mass fraction. After the spiderling total extract was fractionated into high molecular mass and low molecular mass fractions, the effects of the low molecular mass fraction on HeLa cell morphology and apoptosis induction were investigated. The results demonstrated that the low molecular mass fraction at experimental concentrations ( 1 and $100 \mu \mathrm{g} / \mathrm{ml})$ did not induce evident morphological changes in HeLa cells (Fig. 5), suggesting that the effects of the total extract on morphology and apoptosis induction in HeLa cells were not caused by low molecular mass components in the spiderling extract.

In addition, the effect of the low molecular mass fraction on HeLa cell viability was measured. The results (Fig. 6) determined that the components in this fraction had no significant effect on the HeLa cell viability at any concentration $(\mathrm{P}>0.05)$, suggesting that the inhibitory effect of the total extract on HeLa cell viability was primarily attributable to the high molecular mass fraction.

Further separation and activity analysis of high molecular mass fraction. To further evaluate the roles of the high molecular mass fraction, further separation and activity analysis of the fraction was performed. Proteins in the fraction were further fractionated into four primary subfractions based on their sizes using gel filtration chromatography and named P1, P2, P3 and P4 (profile not shown). SDS-PAGE indicated that $\mathrm{P} 1$ was primarily composed of proteins $>35 \mathrm{kDa}$ whereas P4 was composed primarily of proteins $<15 \mathrm{kDa}$ (Fig. 7A). Furthermore, the effects of the subfractions P1-P4 at concentrations of $100 \mu \mathrm{g} / \mathrm{ml}$ on cell viability were determined and it was revealed that all subfraction samples could significantly decrease the viability of HeLa cells $(\mathrm{P}<0.01$; Fig. 7B). This suggests that all the subfractions contain proteinaceous components that strongly decrease cell viability.

As observed in Fig. 7A, of the four subfractions, the purity of $\mathrm{P} 3$ was highest and the subfraction contained one high-abundance band. Therefore, subfraction P3 was selected for further purification with RP-HPLC using a $\mathrm{C}_{4}$ reversed-phase column. The elution curve (Fig. 8) showed a symmetric main peak that was collected for SDS-PAGE analysis. Gel electrophoresis demonstrated that the protein had been purified and had a molecular mass of $\sim 23 \mathrm{kDa}$ (inset in Fig. 8). This purified protein was temporarily named PP23.

To investigate whether the PP23 protein has cytotoxic and apoptotic activities against HeLa cells, the effects of this protein on the cell cycle, cell viability and caspase 3 activity in HeLa cells were detected. The cell cycle profiles of HeLa cells treated with $0,1,5$ and $10 \mu \mathrm{M}$ PP23 protein were analyzed by flow cytometry and the results are presented in Table I. The percentage of the cells in the G0/G1 phase decreased as the concentration of PP23 protein increased, whereas that of the cells in the S-phase remained relatively constant. By contrast, the percentage of the cells in $\mathrm{G} 2 / \mathrm{M}$ phase increased as the concentration of the applied PP23 protein increased. These data suggest that the PP23 protein is able to induce G2/M phase arrest.

When the effect of the PP23 protein on HeLa cell viability was investigated, it was found that following incubation of HeLa cells with PP23 protein at different concentrations $(0,0.01,0.1$, $1,5,10$ and $30 \mu \mathrm{M}$ ), the viabilities of the treated groups were $80.6 \pm 1.70,80.27 \pm 1.27,74.85 \pm 0.49,60.17 \pm 1.19,48.4 \pm 1.45$ and $32.3 \pm 1.92 \%$ of that of the control, respectively, with $\mathrm{IC}_{50}$ being $10.2 \mu \mathrm{M}$. Compared with the control, all the treatments, with the exception of $0.01 \mu \mathrm{M}$ PP23 protein $(\mathrm{P}<0.05)$, significantly decreased the viability of HeLa cells ( $\mathrm{P}<0.01$; Fig. 9A).

Following incubation of HeLa cells with different concentrations of PP23 protein $(0,1,5$ and $10 \mu \mathrm{M})$ for $24 \mathrm{~h}$, caspase 3 activity in HeLa cells was determined. The corresponding 
A

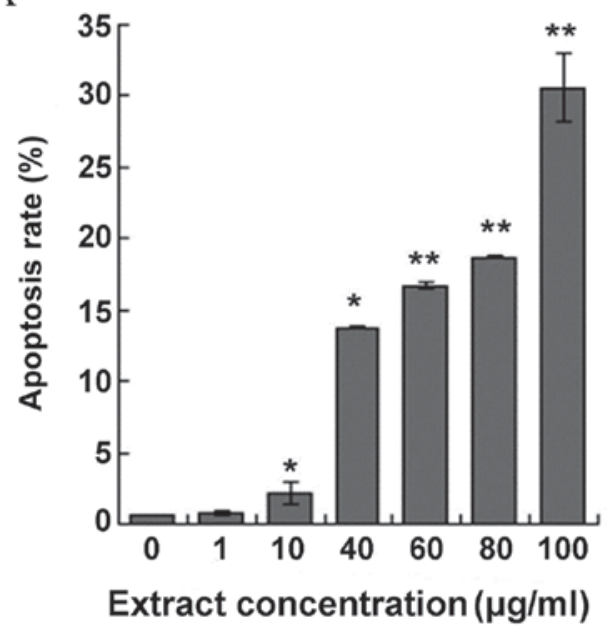

B
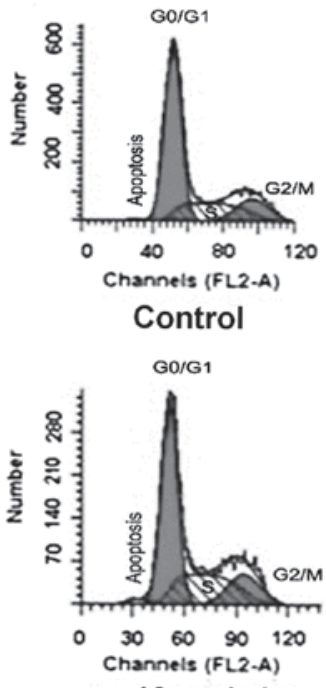

$10 \mu \mathrm{g} / \mathrm{ml}$

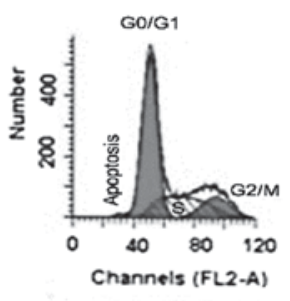

$1 \mu \mathrm{g} / \mathrm{ml}$

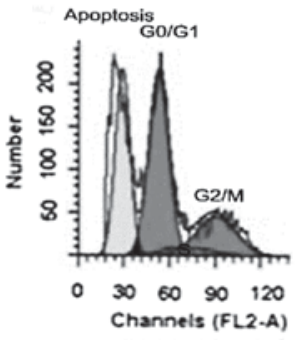

$100 \mu \mathrm{g} / \mathrm{ml}$

Figure 2. Effects of the total extract on cell cycle and apoptosis induction in HeLa cells. HeLa cells were treated with different concentrations of the total extract for $24 \mathrm{~h}$ and then cell cycle and apoptotic rate were analyzed using flow cytometry. (A) Apoptotic rate in HeLa cells caused by treatment with different concentrations $(0,1,10,40,60,80$ and $100 \mu \mathrm{g} / \mathrm{ml})$ of extract. ${ }^{*} \mathrm{P}<0.05$ and ${ }^{* *} \mathrm{P}<0.01$ vs. control. (B) Representative cell cycle profiles of HeLa cells incubated with the extract at the concentrations of $0,1,10$ and $100 \mu \mathrm{g} / \mathrm{ml}$.

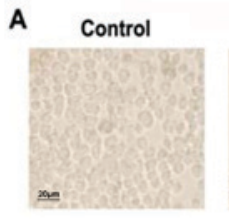

B
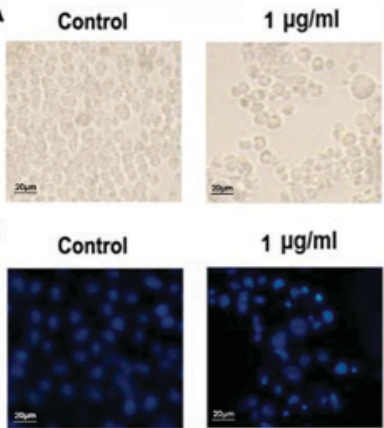

$1 \mu \mathrm{g} / \mathrm{ml}$
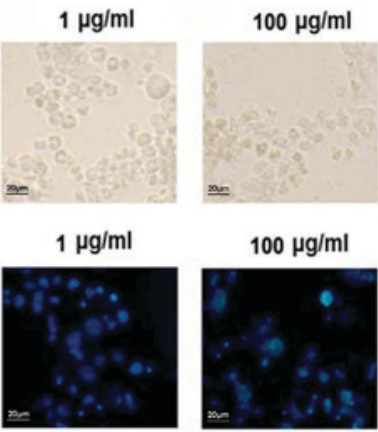

$100 \mu \mathrm{g} / \mathrm{ml}$

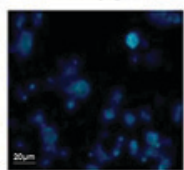

Figure 3. Observations on morphological changes and apoptosis induction in HeLa cells treated with different concentrations $(0,1$ and $100 \mu \mathrm{g} / \mathrm{ml})$ of total spiderling extract. (A) Morphology of HeLa cells incubated with the extract at different concentrations. (B) HeLa cells were incubated with the extract and their nuclei were visualized by Hoechst 33342 staining and fluorescence microscopy.

enzyme activities are presented in Fig. 9B. In the control group, caspase 3 activity was $421.65 \pm 10.32 \mathrm{U} / \mu \mathrm{g}$ protein. Addition of 1,5 and $10 \mu \mathrm{M}$ PP23 protein increased the activity to $529.48 \pm 7.89,667.35 \pm 7.78$ and $710.04 \pm 2.80 \mathrm{U} / \mu \mathrm{g}$ protein, respectively (all $\mathrm{P}<0.01)$.

\section{Discussion}

It is commonly accepted that the anti-tumor effect of cancer drugs is primarily based on inducing apoptosis, blocking DNA synthesis, causing DNA damage and attenuating mitosis (30). Therefore, for over half a century, cytotoxic agents have been studied as a possible treatment for cancer. Many types of animal venom have been found to exert high toxicity on HeLa cells, such as the venoms of toad (8), spider (10), snake (31) and scorpion (32), indicating that these venoms or their components may be utilized as anti-cervical cancer agents.

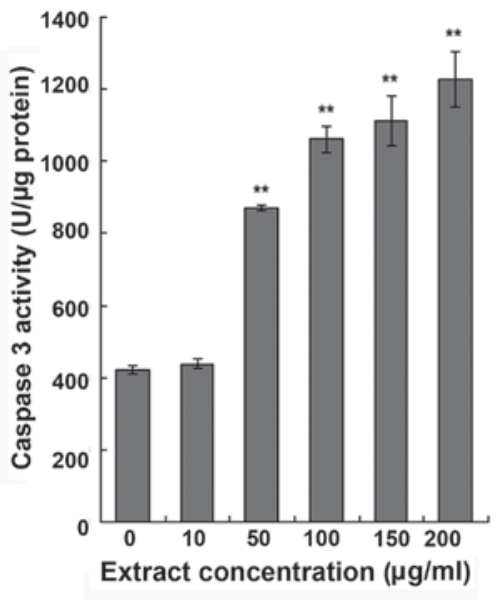

Figure 4. Effect of spiderling total extract on caspase 3 activity in HeLa cells. Following incubation of HeLa cells with different concentrations of the extract $(0,10,50,100,150$ and $200 \mu \mathrm{g} / \mathrm{ml})$, caspase 3 activity in HeLa cells was measured using a commercially available caspase 3 assay kit according to the manufacturer's protocol. Relative activity of the caspase 3 to convert its substrate was expressed as enzyme unit per $\mu$ g protein. ${ }^{* *} \mathrm{P}<0.01$ vs. control.

The anticancer potential of snake venom/toxin(s) has been more extensively studied compared with that of other animal venoms in the field of animal toxin research $(6,15)$. It has been determined that a number of snake venoms and their proteinaceous components can inhibit the tumorigenicity of cancer cells, including HeLa cells. For example, Karthikeyan et al (31) investigated the inhibition of HeLa cell proliferation in vitro using Lapemis curtus (Shaw 1802) venom and found that treatment with $6.50 \mu \mathrm{g} / \mathrm{ml}$ venom for $24 \mathrm{~h}$ effectively inhibited cancer cell proliferation.

The venom from the Cuban scorpion Rhopalurus junceus was demonstrated to exert anticancer effects against HeLa cells in vitro, as evidenced by membrane blebbing, apoptotic 


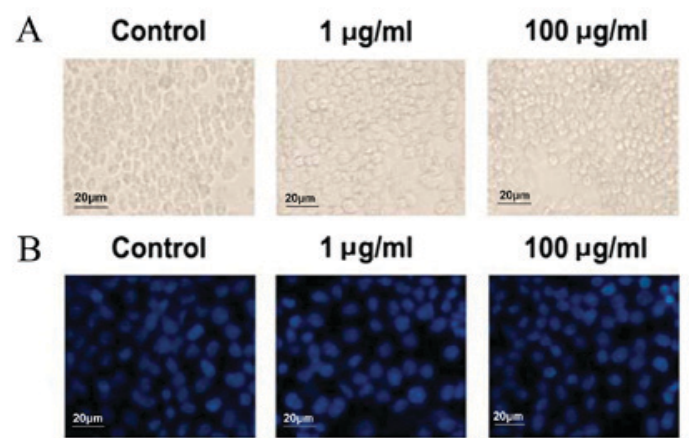

Figure 5. Observations on morphological changes and apoptosis induction in HeLa cells treated with different concentrations $(0,1$ and $100 \mu \mathrm{g} / \mathrm{ml})$ of the low molecular mass fraction from the spiderling total extract. (A) Morphology of HeLa cells incubated with the fraction at different concentrations. (B) HeLa cells were incubated with the fraction and their nuclei were visualized by Hoechst 33342 staining and fluorescence microscopy.

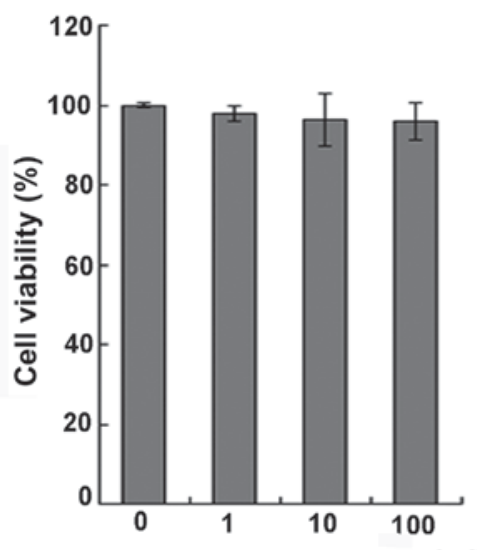

Fraction concentration $(\mu \mathrm{g} / \mathrm{ml})$

Figure 6. Effect of the low molecular mass fraction from the spiderling total extract on HeLa cell viability. Following incubation of HeLa cells with the fraction at different concentrations $(0,1,10$ and $100 \mu \mathrm{g} / \mathrm{ml})$ for $48 \mathrm{~h}$, they were subjected to a cell counting kit- 8 assay. The percentage cell viability was calculated for each group by normalization of the readings at $450 \mathrm{~nm}$ against the absorbance of untreated control HeLa cells, which was designated as $100 \%$ cell viability. Data were represented as the mean \pm standard deviation from three independent experiments.

bodies, nuclear margination and chromatin condensation that occurred in the cells (32). However, the sensitivity of HeLa cells to scorpion venom may vary with the source of the venom. Contreras-Ortiz et al (33) found that the venom from the scorpion Centruroides limpidus was not detrimental to HeLa cell cultures. HeLa cells had high survival rates following exposure to the venom, which did not induce apoptosis and there was no evidence of chromatin condensation or DNA fragmentation (33). Zhang et al (8) investigated the effects of toad venom on HeLa cells by preparing solid lipid nanoparticles loaded with toad venom extract and comparatively studied the anti-tumor effects of such nanoparticles and toad venom extract on HeLa cells in vitro. It was revealed that treatment of HeLa cells with toad venom resulted in gradual changes in cell morphology; the toad venom extract and nanoparticles loaded with the venom inhibited the proliferation of HeLa cells in a dose- and time-dependent manner, and the nanoparticles enhanced the inhibitory activity of toad venom in HeLa cells (8). These results
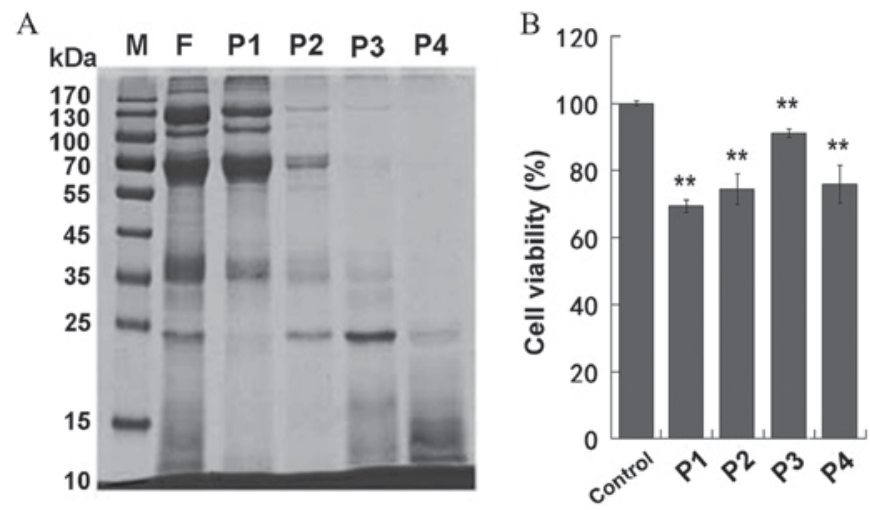

Figure 7. SDS-PAGE of high molecular mass fraction and its subfractions P1 to P4 from (A) gel filtration chromatography and (B) detection of effect of the subfractions on HeLa cell viability. Lane M, molecular mass marker; Lane F, high molecular mass fraction; Lanes P1 to P4, subfractions P1 to P4 from gel filtration chromatography. HeLa cells were seeded in 96-well culture plates and separately treated with the subfractions at a concentration of $100 \mu \mathrm{g} / \mathrm{ml}$. Following incubation for $48 \mathrm{~h}$, cells were subjected to a cell counting kit- 8 assay. Data were represented as the mean \pm standard deviation from three independent experiments. ${ }^{* *} \mathrm{P}<0.01$ vs. control.

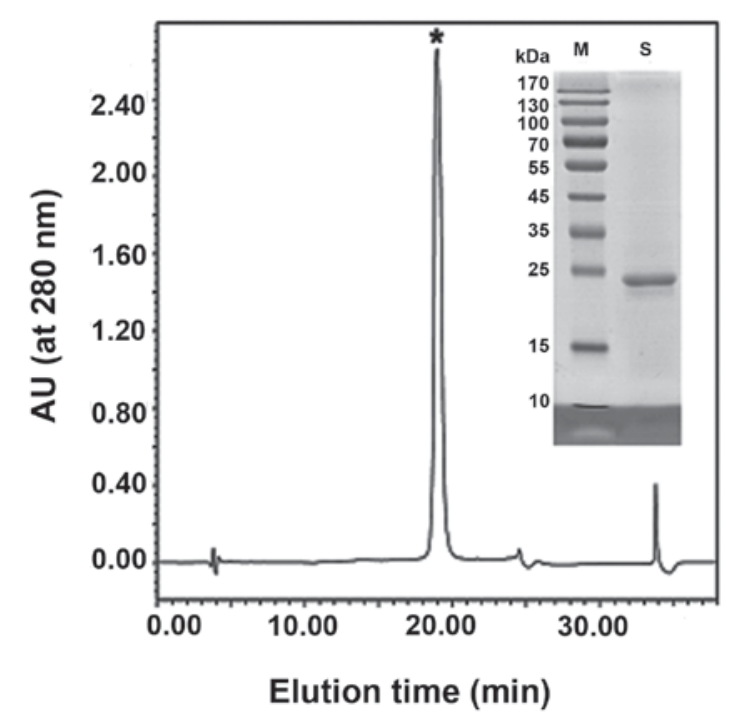

Figure 8. Reversed phase-high-performance liquid chromatography profile of the P3 subfraction from gel filtration chromatography. Inset shows the SDS-PAGE image of the resultant desired peak $\left(^{*}\right)$, which demonstrated that the protein was purified to electrophoretic purity.

indicate that toad venom may be a promising novel treatment for cancer.

Similar to other animal venoms, spider venom is a mixture of numerous bioactive components. It exhibits high cytotoxicity and may be used as a potential cancer therapy. For example, when the effects of spider Macrothele raven venom on cell proliferation and cytotoxicity in HeLa cells were investigated, it was found that the venom could markedly alter the morphology of the cells, and cause dose- and time-dependent inhibition of HeLa cell proliferation. The venom was demonstrated to inhibit the HeLa cells in three ways: Induction of apoptosis, neurosis of toxicity damage and direct lysis (10). In the present study, the black widow spiderling extract, a virtual spider 'venom', was shown to exhibit anticancer activity against HeLa cells in a way 
Table I. Effect of the PP23 protein on the cell cycle profile of HeLa cells.

\begin{tabular}{lccc}
\hline & \multicolumn{3}{c}{ Cell cycle phase, \% } \\
\cline { 2 - 4 } $\begin{array}{l}\text { PP23 } \\
\text { concentration, } \mu \mathrm{M}\end{array}$ & $\mathrm{G} 0 / \mathrm{G} 1$ & $\mathrm{~S}$ & $\mathrm{G} 2 / \mathrm{M}$ \\
\hline 0 (control) & $50.48 \pm 1.10$ & $37.89 \pm 1.87$ & $8.47 \pm 1.21$ \\
1 & $50.03 \pm 1.88$ & $36.56 \pm 0.19$ & $10.45 \pm 1.60$ \\
5 & $47.88 \pm 0.95^{\mathrm{a}}$ & $37.66 \pm 1.34$ & $10.74 \pm 1.41$ \\
10 & $44.50 \pm 3.17^{\mathrm{a}}$ & $37.06 \pm 3.04$ & $14.52 \pm 1.40^{\mathrm{b}}$ \\
\hline
\end{tabular}

${ }^{\mathrm{a}} \mathrm{P}<0.05$ vs. control; ${ }^{\mathrm{b}} \mathrm{P}<0.01$ vs. control.
A

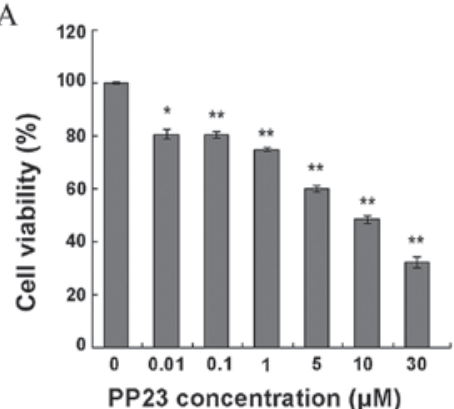

B

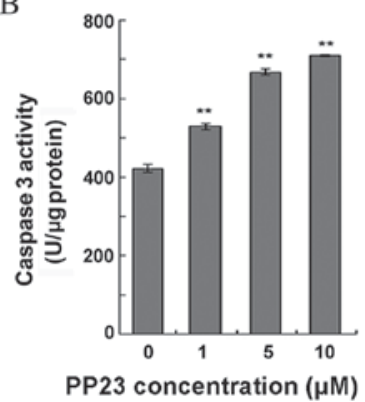

Figure 9. Effects of PP23 protein on (A) cell viability following treatment with $0,0.01,0.1,1,5,10$ and $30 \mu \mathrm{M}$ PP23 protein and (B) caspase 3 activity following treatment with $0,1,5$ and $10 \mu \mathrm{M}$ PP23 protein in HeLa cells. Data were represented as the mean \pm standard deviation from three independent experiments. ${ }^{*} \mathrm{P}<0.05$ and ${ }^{* *} \mathrm{P}<0.01$ vs. control.

somewhat similar to that of some other animal venoms. When applied at various concentrations (1-900 $\mu \mathrm{g} / \mathrm{ml})$, the spiderling total extract decreased HeLa cell viability in a dose-dependent manner, with the $\mathrm{IC}_{50}$ being $158 \mu \mathrm{g} / \mathrm{ml}$ (Fig. 1).

To determine the mechanism of cell viability inhibition caused by the total extract, the effect of the total extract on apoptosis was investigated in HeLa cells. The results indicated that the total extract contained active components able to induce apoptosis in HeLa cells. These results were supported by the changes in cell morphology and the increase in caspase 3 activity observed in HeLa cells treated with the total extract. Caspase 3 is one of the key executioners of apoptosis. During the execution phase of apoptosis, caspase 3 is responsible either wholly or in part for the proteolytic cleavage of numerous key proteins (34).

The normal growth of cells depends on strictly controlled stages of the cell cycle (35). A number of anti-cancer agents have been reported to arrest the cell cycle at specific points and thereby induce apoptotic cell death $(36,37)$. Furthermore, it has been demonstrated that several animal venoms contain bioactive components that induce apoptosis and necrosis of HeLa cells by altering the cell cycle distribution. Gao et al (10) reported that following treatment with spider Macrothele raven venom, the number of HeLa cells in the $\mathrm{S}$ and G2/M phases decreased and the percentage of cells in the G0/G1 phase increased. It was thus concluded that the inhibitory effect of the spider venom on growth of the cells may result from G0/G1 cell cycle arrest (10).
However, different venoms may block the cell cycle of HeLa cells at different points. It was indicated that toad venom from Bufo bufo gargarizans Cantor or Bufo melanostictus Schneider, different from the aforementioned spider venom, decreased the percentage of HeLa cells in the G0/G1 phase and increased the number of HeLa cells in the $\mathrm{S}$ and G2/M phases. Thus, the $\mathrm{S}$ and G2/M phases were blocked following the incubation of HeLa cells with the toad venom (8).

In the present study, S-phase arrest was observed in HeLa cells treated with spiderling total extract $10 \mu \mathrm{g} / \mathrm{ml}$. DNA content and distribution of HeLa cells detected by flow cytometry indicated that the total extract applied in a relative low concentration range $(1,10 \mu \mathrm{g} / \mathrm{ml})$ blocked the cells in the S-phase in a dose-dependent manner, while a higher concentration of the extract $(100 \mu \mathrm{g} / \mathrm{ml})$ directly induced apoptosis of a high percentage of cells $(30.60 \pm 2.35 \%)$. These results indicate that the spiderling total extract can efficiently inhibit cell growth and induce cell apoptosis in HeLa cells with a markedly different action mechanism from that of spider Macrothele raven venom, but a similar mechanism to that of toad venom.

The spiderling total extract is a complex mixture. To further characterize the cytotoxic and apoptotic activities of the extract, it was divided into high- and low- molecular-mass fractions and it was revealed that such activities were primarily attributed to the proteins with higher molecular masses. This seems to differ from other animal venoms, including snake venom, of which a number of proteins and low molecular mass peptides are able to efficiently inhibit the proliferation of HeLa cells $(6,31,38)$. After the high molecular mass fraction was further separated into four subfractions, all were found to significantly decrease cell viability $(\mathrm{P}<0.01)$, indicating that the fraction was rich in the relevant active proteins. The purified PP23 protein was demonstrated to be one such active protein. The experimental results demonstrated that the PP23 protein decreased HeLa cell viability, stimulated caspase 3 activity and induced cell cycle arrest in HeLa cells. It is important to point out that the PP23 protein blocked the HeLa cell cycle in the $\mathrm{G} 2 / \mathrm{M}$ phase, which differed from the mechanism of action of the spiderling total extract, which induced S-phase arrest. This observation suggests that there are other active proteins in the total extract that affect the cell cycle with different mechanisms. Further studies are required to determine the mechanism of action of these other proteins.

In conclusion, the current study has demonstrated that the newborn black widow spiderling total extract possesses strong cytotoxic and apoptotic activities against HeLa cells. It is able to induce apoptosis, alter cell morphology, arrest the cell cycle and decrease cell viability. It was determined that the proteins with higher molecular masses in the total extract were the primary substances responsible for the anticancer activity. This was supported by the observations of PP23 activity, a $23 \mathrm{kDa}$-protein purified from the total extract. Therefore, the high molecular mass proteins contained within the black widow spiderling extract may be developed as a novel treatment for cervical cancer.

\section{Acknowledgements}

The present study was supported by grants from the National Natural Science Foundation of China (grant nos. 31070700 
and 31271135) and the Cooperative Innovation Center of Engineering and New Products for Developmental Biology of Hunan Province (grant no. 20134486).

\section{References}

1. Jemal A, Bray F, Center MM, Ferlay J, Ward E and Forman D: Global cancer statistics. CA Cancer J Clin 61: 69-90, 2011.

2. Niwa H, Rowbotham DJ, Lambert DG and Buggy DJ: Can anesthetic techniques or drugs affect cancer recurrence in patients undergoing cancer surgery? J Anesth 27: 731-741, 2013.

3. Bray F, Ren JS, Masuyer E and Ferlay J: Global estimates of cancer prevalence for 27 sites in the adult population in 2008. Int J Cancer 132: 1133-1145, 2013.

4. Boveri T: Concerning the origin of malignant tumours by Theodor Boveri. Translated and annotated by Henry Harris. J Cell Sci 121 (Suppl 1): S1-S84, 2008.

5. Garraway LA and Lander ES: Lessons from the cancer genome. Cell 153: 17-37, 2013.

6. Calderon LA, Sobrinho JC, Zaqueo KD, de Moura AA Grabner AN, Mazzi MV, Marcussi S, Nomizo A, Fernandes CF, Zuliani JP, et al: Antitumoral activity of snake venom proteins: New trends in cancer therapy. Biomed Res Int 2014: 203639, 2014

7. Liu YF, Ma RL, Wang SL, Duan ZY, Zhang JH, Wu LJ and Wu CF: Expression of an antitumor-analgesic peptide from the venom of Chinese scorpion Buthus martensii Karsch in Escherichia coli. Protein Expr Purif 27: 253-258, 2003.

8. Zhang SJ, Zhang YT, Zhao JH, Shen LN, Shen LN, Shi F and Feng NP: Preparation and in vitro anti-tumor properties of toad venom extract-loaded solid lipid nanoparticles. Pharmazie 68 653-660, 2013

9. Orsolić N, Sver L, Verstovsek S, Terzić S and Basić I: Inhibition of mammary carcinoma cell proliferation in vitro and tumor growth in vivo by bee venom. Toxicon 41: 861-870, 2003.

10. Gao L, Shan BE, Chen J, Liu JH, Song DX and Zhu BC: Effects of spider Macrothele raven venom on cell proliferation and toxicity in HeLa cells. Acta Pharmacol Sin 26: 369-376, 2005.

11. Haas JA, Witten MR, Clancey O, Episcopia K, Accordino D and Chalas E: CyberKnife boost for patients with cervical cancer unable to undergo brachytherapy. Front Oncol 2: 25-29, 2012.

12. Qureshi AA and Saavedra A: Palmar fasciitis and polyarthritis syndrome in patients with ovarian cancer-a case report and review of the literature. Hand (N Y) 6: 220-223, 2011.

13. Rodríguez Villalba S, Díaz-Caneja Planell $\mathrm{C}$ and Cervera Grau JM: Current opinion in cervix carcinoma. Clin Trans Oncol 13: 378-384, 2011.

14. Xin N, Hasan M, Li W and Li Y: Juglans mandshurica Maxim extracts exhibit antitumor activity on HeLa cells in vitro. Mol Med Rep 9: 1313-1318, 2014.

15. Gomes A, Bhattacharjee P, Mishra R, Biswas AK, Dasgupta SC and Giri B: Anticancer potential of animal venoms and toxins. Indian J Exp Biol 48: 93-103, 2010.

16. Dyer N: Venom: Miracle medicine? Sci World 56: 8, 1999.

17. Benjamin CW, Hiebsch RR and Jones DA: Caspase activation in MCF7 cells responding to etoposide treatment. Mol Pharmacol 53: 446-450, 1998

18. Akhunov AA, Golubenko Z, Abdurashidova NA, Mustaklmova ECH, Ibraglmov FA and Mackessy S: Comparative biochemistry of the physiologically active components of venom, hemolymphy and eggs of the karakurt spider (Latrodectus tredecimguttatus). Chem Nat Compd 37: 562-565, 2001.

19. Buffkin DC and Russell FE: A poison from the eggs and spiderlings of the black widow spider. Pro West Pharmac Soc 14: 166, 1971.

20. Buffkin DC, Russell FE and Deshmukh A: Preliminary studies on the toxicity of black widow spider eggs. Toxicon 9: 393-402, 1971.
21. Yan S and Wang X: Recent advances in research on widow spider venoms and toxins. Toxins (Basel) 7: 5055-5067, 2015.

22. Shackleford R, Veillon D, Maxwell N, LaChance L, Jusino T, Cotelingam $J$ and Carrington P: The black widow spider bite: Differential diagnosis, clinical manifestations, and treatment options. J La State Med Soc 167: 74-78, 2015.

23. Rohou A, Nield J and Ushkaryov YA: Insecticidal toxins from black widow spider venom. Toxicon 49: 531-549, 2007.

24. Ushkaryov YA, Volynski KE and Ashton AC: The multiple actions of black widow spider toxins and their selective use in neurosecretion studies. Toxicon 43: 527-542, 2004.

25. Li J, Liu H, Duan Z, Cao R, Wang X and Liang S: Protein compositional analysis of the eggs of black widow spider (Latrodectus tredecimguttatus): Implications for the understanding of egg toxicity. J Biochem Mol Toxicol 26: 510-515, 2012.

26. Kobert R: Lehrbuch der Anatomie der Sinnesorgane. Biol Zbl 8: 287-766, 1889.

27. Peng X, Zhang Y, Liu J, Yu H, Chen J, Lei Q, Wang X and Liang S: Physiological and biochemical analysis to reveal the molecular basis for black widow spiderling toxicity. J Biochem Mol Toxicol 28: 198-205, 2014.

28. Laemmli UK: Cleavage of structural proteins during the assembly of the head of bacteriophage T4. Nature 227: 680-685, 1970.

29. Garcia-Jove Navarro M, Basset C, Arcondéguy T, Touriol C, Perez G, Prats H and Lacazette E: Api5 contributes to E2F1 control of the G1/S cell cycle phase transition. PLoS One 8: e71443, 2013.

30. Jiang N, Wang X, Yang Y and Dai W: Advances in mitotic inhibitors for cancer treatment. Mini Rev Med Chem 6: 885-895, 2006.

31. Karthikeyan R, Karthigayan S, Sri Balasubashini M, Somasundaram ST and Balasubramanian T: Inhibition of Hep2 and HeLa cell proliferation in vitro and EAC tumor growth in vivo by Lapemis curtus (Shaw 1802) venom. Toxicon 51: 157-161, 2008.

32. Diaz-García A, Morier-Díaz L, Frión-Herrera Y, RodríguezSanchez H, Caballero-Lorenzo D, Riquenes-Garlobo Y and Fraga-Castro JA: In vitro anticancer effect of venom from Cuban scorpion Rhopalurus junceus against a panel of human cancer cell lines. J Venom Res 4: 5-12, 2013.

33. Contreras-Ortiz JM, Vázquez-Chagoyán JC, MartínezCastañeda JS, Estrada-Franco JG, Aparicio-Burgos JE, Acosta-Dibarrat $\mathbf{J}$ and Barbabosa-Pliego A: Resistance of cervical adenocarcinoma cells (HeLa) to venom from the scorpion Centruroides limpidus limpidus. J Venom Anim Toxin Incl Trop Dis 19: 20, 2013.

34. Cohen GM: Caspases: The executioners of apoptosis. Biochem J 326: 1-16, 1997.

35. Murray AW: Recycling the cell cycle: Cyclins revisited. Cell 116: 221-234, 2004.

36. Lu YJ, Yang SH, Chien CM, Lin YH, Hu XW, Wu ZZ, Wu MJ and Lin SR: Induction of $\mathrm{G} 2 / \mathrm{M}$ phase arrest and apoptosis by a novel enediyne derivative, THDB, in chronic myeloid leukemia (HL-60) cells. Toxicol In Vitro 21: 90-98, 2007.

37. Gamet-Payrastre L, Li P, Lumeau S, Cassar G, Dupont MA, Chevolleau S, Gasc N, Tulliez J and Tercé F: Sulforaphane, a naturally occurring isothiocyanate, induces cell cycle arrest and apoptosis in HT29 human colon cancer cells. Cancer Res 60: 1426-1433, 2000.

38. Teklemariam T, Seoane AI, Ramos CJ, Sanchez EE, Lucena SE, Perez JC, Mandal SA and Soto JG: Functional analysis of a recombinant PIII-SVMP, GST-acocostatin; an apoptotic inducer of HUVEC and HeLa, but not SK-Mel-28 cells. Toxicon 57: 646-656, 2011. 